\title{
The Effect of Teaching Vocabulary through Semantic Mapping on EFL Learners' Awareness of the Affective Dimensions of Deep Vocabulary Knowledge
}

\author{
Somayeh Nilforoushan ${ }^{1}$ \\ ${ }^{1}$ Faculty of Foreign Languages, Islamic Azad University, Central Tehran Branch, Tehran, Iran \\ Correspodence: Somayeh Nilforoushan, Faculty of Foreign Languages, Islamic Azad University, Central Tehran \\ Branch, Tehran, Iran. Tel: 98-21-8833-85796. E-mail: somayeh.nil@gmail.com
}

Received: June 9, 2012 Accepted: June 28, 2012 Online Published: August 23, 2012

doi:10.5539/elt.v5n10p164 URL: http://dx.doi.org/10.5539/elt.v5n10p164

\begin{abstract}
This study focused on the effect of teaching vocabulary through semantic mapping on the awareness of two affective dimensions, evaluation and potency dimensions of deep vocabulary knowledge as well as the general vocabulary knowledge of EFL students. Sixty intermediate EFL female adult learners participated in this study; they were chosen among 90 students through Prelemenary English test and a general vocabulary knowledge test. They were thus randomly divided into two group, experimental and control, each consisting of 30 students. As for the treatment, modifiers describing peoples' characteristics were taught in the text and through semantic mapping, whereas these words were taught by usual vocabulary instruction in control group. At the end, students took a vocabulary achievement test and a test of awareness of evaluation and potency dimensions of deep vocabulary knowledge. A t-test was run to analyze the data from the vocabulary achievement test. Results showed that teaching collocations has great influence on the students' general vocabulary knowledge. To see if the independent variable had significant effects on awareness of evaluation and potency dimensions of deep vocabulary knowledge, a MANOVA was run revealing that teaching vocabularies through semantic mapping significantly improved learners`awareness of the two dimensions.
\end{abstract}

Keywords: semantic mapping, deep vocabulary knowledge, evaluative dimension, potency dimension

\section{Introduction}

\subsection{Overview}

Vocabulary is an inseperable part of any language learning process. It would be imposible to learn a language without vocabulary. The important role that this component plays has been emphasized in all the different methods of language teaching. Rivers (1981) states, "vocabulary cannot be taught. It can be presented, explained, included in all kinds of activities, but it must be learnt by individuals" (p. 28). She further states that, "As language teachers, we must arouse interest in words, a certain excitement I personal development in this area" (p. 29). She also suggests that language teachers must help their students by giving them ideas on how to learn vocabulary and some guidance on what to learn.

Vocabulary as a major component of language learning has been the object of numerous studies each of which has its own contribution to the field. Laufer (1997) considers vocabulary learning as the heart of language learning and language use. In fact, it is this vocabulary learning that makes the essence of any language. Without vocabularies, speakers cannot convey meaning and communicate with each other in any particular language.

As a teacher, the researcher has encountered with many students who have considerable vocabulary knowledge. They, however, fail to use them correctly in different domains. Learners, mainly, the upper intermediate and advanced ones, are often able to produce grammatically correct sentences. However, they produce very plain utterances which are unable to convey different emotional loads or to express shades of intensity of connotations.

It seems that this problem is due to lack of depth vocabulary knowledge and that the students' criterian in choosing words in context is surface structure and they fail to address the depth of vocabulary knowledge. Iranian EFL learners ' poor deep vocabulary knowledge is a matter of concern among those involved in education and their quest for finding suitable remedies is getting more and more intense. Thus, this study was conducted to 
see whether teaching vocabularies through semantic mapping was an effective technique in increasing the affectvie dimensions of learners' deep vocabulary knowledge, especially evaluative and potency dimensions.

\subsection{Semantic Mapping}

Barcroft (2004, p. 200) defines semantic mapping as "the increased evaluation of an item with regard to its meaning". A semantic mapping can be used as a tool for discovering the conceptual relationship between vocabulary items. Semantic elaboration seems to enhance word learning and retention, through a learning phase called integration (Shostak, 2003). Integration is based on the view that in order for learning to occur, new information should be incorporated into what the learner previously knows (Christen \& Murphy, 1981, cited in Shostak 2003). That is instruction should guide learners to use words and ideas available to them in their word and concept repertoire to help them associate meaning with words they do not know. It is believed that this will lead to deeper learning and thus longer retention of the learned words. Previous research on vocabulary acquisition reveals a significant improvement in vocabulary learning whenever semantic maps were employed. Harley, Howard, and Roberge (1996), for instance, employed semantic maps in two French-as-a-second-language classes. The findings of their study were indicative of a significant degree of gain in vocabulary knowledge in both classes over the three to four weeks of treatment.

Barcroft (2004) argues that semantic elaboraton of lexical items enhances their memory retention considerably among L2 learners. Based on previous research studies conducted and their findings, Barcoft (2004, p. 201) asserts that:

Semantic elaboration positively affects memory for (a) previously acquired words (Bower \& Reitman, 1972; Craik \& Tulving, 1975; Johnson-Laird, Gibbs, \& de Mowbray, 1978; Hyde \& Jenkins, 1969; Ross 1981; Schuman, 1974, Tresselt \& Mayzner, 1960); (b) new words recorded as known words (Atkinson \& Raugh, 1975; Levin Et al., 1982; Pressley et al., 1982; Ellis \& Beaton, 1995) and (c) other types of stimuli (e.g. first language sentence recall: Stevenson, 1981; L1 text recall: McDaniel, 1984).

In the same way, Bromley, Irwin-Devitis, and Modlo, (1995) asserts that graphic organizers represent a graphic teaching strategy which has been devised to help learners build the conceptual connotations they need to decipher any kind of words completely. It is this graphic feature of semantic maps that inspired the present study in exploring a potential gain for learners with different perceptual modalities when vocabulary is taught and learned through these graphic organizers.

\subsection{Evaluative and Potency Dimensions of Deep Vocabulary Knowledge}

Deep vocabulary knowledge involves how well a person knows a word, in contrast to breath of vocabulary knowledge which involves how many words are known (Brown, 2007).

Evaluative dimension of vocabulary knowledge refers to how good or bad something is, that is, whether the entity has people's approval or disapproval in terms such as good vs. bad (Hiese 2002: 37). People may evaluate something as positive such as adjective "good" and they may evaluate something as negative such as adjective "bad".

Potency dimensions of deep vocabulary knowledge refers to an entity's impact in terms of being big verses little, powerful verses powerless, consequential verses immaterial (Heise 2002: 37). Potency shows the range of power or impact of an entity. "Powerful" is a potent adjective because it has the greatest impact, whereas "powerless" is non potent because it has the least impact.

\subsection{Research Questions}

There is no evidence to prove that Iranian learners of English pay attention to the affective dimensions of vocabulary knowledge in their vocabulary use as well. Therefore, the current study examined the effect of teaching vocabularies through semantic mapping on the affective dimensions of EFL learners' vocabulary knowledge. According to Osgood, May and Miron (1975), deep vocabulary knowledge involves evaluation, potency, and activity of vocabularies. The effect of teaching vocabularies through semantic mapping on increasing the awareness of the evaluation and potency dimension of deep vocabulary knowledge was the focus of this study with the following three research questions formulated:

1. Does teaching vocabularies through semantic mapping have any significant effect on Iranian EFL Learners` overall vocabulary achievement?

2. Does teaching vocabularies through semantic mapping have any significant effect on Iranian EFL learners` awareness of evaluative dimension of vocabulary?

3. Does teaching vocabulary through semantic mapping have any significant effect on Iranian EFL learners` 
awareness of potency dimension of vocabulary?

\section{Method}

\subsection{Participants}

The participants of this study were 60 Iranian adult intermediate EFL learners selected from 90 intermediate students based on their performance on the Preliminary English Test (PET) and a general vocabulary test to assure their homogeneity. The 90 students were randomly chosen from all the students studying at the intermediate level of Kish Language School in Tehran. Then they were randomly divided into two groups of 30 students: one group as the control group and the other one as the experimental one. All the participants were female and had been studying English for about two years. The whole term took 20 sessions each one lasting 90 minutes.

\subsection{Instrumentations}

A sample PET was used to select 60 participants from 90 intermediate learners. The test had three sections including listening part (25 questions), reading part (35 questions) and five questions of fill-in-the-blanks for the writing part. Before the main administration, the test was piloted among 30 intermediate students who were not the main subjects of this study. item facility and item discrimination indices were calculated.

Alongside the PET, a test of general vocabulary knowledge was constructed and used for homogenizing the participants. This test consisted of 40 multiple-choice items and the questions were made based on the vocabulary presented in the intermediate level books of "new interchange" and "True to Life". The vocabulary test was made based on the topics such as jobs, people, human characteristics and feelings, disasters, expressions, prepositions, and animals. The test was piloted among 30 intermediate students who were not the main subjects of this study. all the items were checked regarding their item facility and item discrimination. The average score of students on the PET and vocabulary test were used for homogenizing the selected participants.

Moreover, a test of vocabulary achievement was used as the posttest for determining whether teaching vocabularies through semantic mapping had any effect on the overall vocabulary achievement of students. The test had 40 multiple choice items, and the vocabularies were chosen based on the topics similar to the topics of the test which had been used for homogenization. This test was also piloted by administrating it among another 30 intermediate students. All the items were checked in terms of item facility and item discrimination.

Finally, a test was designed to assess the participants`awareness of evaluative and potency dimensions of vocabulary knowledge. In this test, the students were given 20 sentences and for each they had to choose adjectives from a list of 20 for the names of people in the given sentences by paying attention to the verb. This test was used at the end of the term as another posttest. For preparing this test, 20 adjectives that describe human characteristics and 20 verbs that are used for the interpersonal domain were taken from Carrigon tables of evaluatin and potency (2002) which has the classification for positive/negative and potent/non-potent adjectives and verbs. Five verbs and adjectives were potent and positive such as confident, five were potent and negative such as selfish, five were non-potent and positive such as polite, and five were non-potent and negative such as dishonest. All the verbs and adjectives were the ones which are normally used in interpersonal interaction. The names were paired with two proper names to form the sentence such as "John hit Ted". Students had to choose one of the adjectives that they thought would be the best descriptor for each of the nouns in the sentence. The test was scored twice, once to msasure the evaluation dimension of students vocabulary knowledge and once to measure the potency dimension of the vocabulary knowledge.

\subsection{Procedure}

Prior to the experiment the two vocabulary tests, the PET, and the test of awareness of affective dimensions of vocabulary knowledge was piloted on 30 intermediate students who were not the main subjects of this study.

For choosing and homogenizing 60 participants for this experiment, the PET and the test of general vocabulary knowledge were given to 90 intermediate Iranian EFL learners. Their average scores in these two tests were used for homogenizing them, and those who achieved scores between one standard deviation above and below the mean were chosen.

Subsequently, the 60 participants were randomly divided into two groups of 30 students. One group participated as the control group for whom adjectives were thought through usually vocabulary instruction. In the experimental group, however, these vocabularies were taught through semantic mapping method.

the following timeframe was set: a 45 minute portion of the standard 90 minute class time was devoted to usual class activities and covering the textbook; the remaining 45 minutes were dedicated to grouping vocabularies 
items using graphic organizers for the experimental group and the usual vocabulary instruction techniques for the control group (e.g. providing English synonyms and definitions, referring the learners to their dictionaries, giving Farsi equivalent, etc. both groups discussed the reading passages and their content and vocabulary.

Twenty sessions of treatment were hold over twenty period in both classes. The treatment involved a reading passage with commonplaces reading instruction practices, including a warm-up, introduction of a reading skill, and reading the text while applying the newly learned skills to answer the comprehension questions that follow each text in the original format of the textbook. In the second half of the class time, however, learners in the control and experimental group followed different paths. The control group received the usual vocabulary instruction wheras the experimental group participated in the semantic elaboration activities.

The semantic maps, which were used for the treatment in the experimental group, were descriptive or thematic maps, spider maps, problem and solution maps, and fishbone maps. The maps for the first two reading passages were filled by the learners with the teachers' assistance. For the last two passages, however, they were assigned to the learners to fill in groups or four or five people. The teacher only observed and provided help if needed in this phase. The resulting maps which were checked to ascertain whether they had accommodated all the target lexical items or not were finally approved by the teachers.

At the end of the term, all students took two tests as posttests: a test of vocabulary achievement to compare the control and experimental groups' performance on it, and a test for determining the students awareness of evaluation and potency dimensions of vocabulary knowledge which was scoresd twice for the two dimensions. First, it was scored paying attention to whether students chose potent adjectives for nouns in the sentences in which verbs were potent, and whether students chose the non-potent adjectives for noun in the sentences in which non-potent verbs were used. In the case where there was congruence between the potency of the verb and the potency of the adjectives,, students received one score and the total score out of 34 (the number of the sentences on the test) was calculated.

In the next stage, the same test was scored based on the evaluation of verbs and adjectives to see whether students had chosen positive adjectives for the nouns in the sentences in which verbs were positive and negative adjectives for the nouns in sentences in which verbs were negative. Any congruentce between adjectives and verbs regarding their evaluation received one mark and the total score was calculated our of 20.

Then, a Multivariate Analysis of Variance (MANOVA) was run to compare the control and experimental groups awareness of the potency and evaluation dimensions of deep vocabulary knowledge, and to see if there were significant differences between them. The control and experimental groups'scores on the vocabulary achievement posttest was also compared statistically by means of t-test to see whether there was a significant difference between their vocabulary knowledge after the treatment.

\subsection{Design}

The design of this research is experimental there were two groups, one group as an experimental one and one as a control group. The treatment was teaching vocabularies through semantic mapping to experimental group. At the end of the term, both groups participated in post test. T-test was used for comparing the experimental and control groups.

The independent variable in this study was "teaching through semantic mapping". Dependent variables were "awareness of potency dimensions of deep vocabulary knowledge" and "general vocabulary knowledge". The controlled variable in this study was "gender".

\section{Results}

Prior to discussing the results, it should be noted that the design of this reach was experimental since the participants were selected from 90 students by a pretest. Random sampling was carried out in chooing the 90 students. To intitiate the experiment, 90 intermediate students took part in a PET and a general vocabulary test. Both were primarily piloted ( as described earlier) with their reliability indices using the Cronboth Alpha index being 0.98 and 0.9 , resepectively. Hence, both tests were used to homogenize the participants required for this study and the average scores of students on the PET and the vocabulary test were used as thee criterion fo selection.

At the end of the instruction period, the students in both groups took part in a general vocabulary achievement test and a test for measuring awareness of evaluation and potency dimensions of deep vocabulary knowledge. First, both tests were piloted. The reliability of the vocabulary posttest was 0.97 again through the Cronbothalpha which is highly acceptable, thus reassuring the researchers that they could use this test for the first analysis. 
Table 1. Descriptive statistics of the two groups on the vocabulary achievement posttest

\begin{tabular}{lllllll}
\hline & \multirow{2}{*}{$\mathrm{N}$} & \multirow{2}{*}{ Mean } & \multirow{2}{*}{ Std. Deviation } & \multirow{2}{*}{ Std Error Mean } & Skewness & \\
\cline { 6 - 7 } & & & & Statistics & Stamdard error \\
\hline Exp & 30 & 27.80 & 12.607 & 2.302 & -1.247 & 0.427 \\
\hline Cont & 30 & 18.20 & 13.717 & 2.504 & 0.025 & 0.427 \\
\hline
\end{tabular}

As table 1 indicates, while the scores of the control group represent normality of distribution $(0.025 / 0.427=0.05$ which falls within the acceptable arrange of \pm 1.96 ), the experimental groups skewnees ratio was skewed. Hence, a nonparametric test was used instead of the t-test. Table 2 and 3 below show the results of this statistical procedure.

Table 2. Ranks of the two groups on the vocabulary achievement test

\begin{tabular}{llll}
\hline Group & $\mathrm{N}$ & Mean & Sum of ranks \\
\hline Experimental & 30 & 37.03 & 1110.00 \\
\hline Control & 30 & 23.97 & 719.00 \\
\hline
\end{tabular}

Table 3. Mann-Whitney test: test statistics

\begin{tabular}{ll}
\hline Mann-Whitney U & 254.000 \\
\hline Wiilcoxon W & 719.000 \\
\hline Z & -2.906 \\
\hline Asymp. Sig. (2-tailed) & 0.004 \\
\hline
\end{tabular}

According to table 3, the results of the Mann-Whitney test indicated that at the 0.05 level of significance, there was a significant difference between the mean rank of the control group (23.97) and that of experimental group (37.03) on the vocabulary posttest $(\mathrm{U}=254, \mathrm{~N} 1=30, \mathrm{~N} 2=30, p=0.004<0.05)$.

Accordingly, the research hypothesis stating that vocabulary teaching through semantic mapping does not significantly affect vocabulary achievement was rejected, and since the experimental group outperformed the control group by obtaining a higher mean score, one may safely conclude that the treatment, i.e. teaching vocabulary through semantic mapping, helped the learners' vocabulary achievement.

The next stage was to address the second and third research questions on the participants dimensions of vocabulary knowledge through MANOVA. First, using the Cronbach alph index, the researchers calculated the reliability fo the test for investigating the evaluation dimension of vocabulary knowledge; these two indices were 0.91 amd 0.94 , respectively.

Next, the normality of distributions of the scores was checked. Since the distributions were skewed, the researchers omitted the outliers and as a result, the number of participants was reduced to 26 in the experimental group and 24 in the control group. Table 4 below depicts the descriptive statistics pertaining to the two groups' scores on the two dimensions of vocabulary knowledge test after the omission of the outliers from the original distribution of scores.

Table 4. Descriptive statistics of the two groups` scores on the dimensions of the vocabulary knowledge test

\begin{tabular}{llllll}
\hline & \multirow{2}{*}{$\mathrm{N}$} & \multirow{2}{*}{ Mean } & $\begin{array}{l}\text { Std. } \\
\text { Deviation }\end{array}$ & Skewness & \\
\cline { 6 - 6 } Evaluation & & & & & Statistic \\
\hline Cont & 24 & 10.13 & 3.09 & -0.234 & 0.481 \\
\hline Exp & 26 & 22.32 & 2.98 & -0.543 & 0.464 \\
\hline Potency & & & & & 0.481 \\
\hline Cont & 24 & 8.09 & 5.23 & 0.33 & 0.464 \\
\hline Exp & 26 & 20.76 & 7.27 & 0.452 & \\
\hline
\end{tabular}


The distribution of scores came out to be normal (skewness ration of 0.48 for the control group's evaluative dimension, 1.17 for the experimental groups' evaluative dimension, 0.68 for the control group's potency dimension, and 0.97 for the experimental group's potency dimension which all fell within the acceptable range) after the omission of outliers.

The assumption of homogeneity of Variance was also met based on the $p$ values of 0.892 and 0.05 reported in table 5 below.

Table 5. Test of Homogenity of Variance

\begin{tabular}{lllll}
\hline & $\begin{array}{l}\text { Levence } \\
\text { Statistics }\end{array}$ & Df1 & Df2 & Sig. \\
\hline CG. EVALU & .019 & 1 & 46 & 0.892 \\
Based on mean & 0.110 & 1 & 46 & 0.742 \\
Based on median & 0.110 & 1 & 45.63 & 0.742 \\
Based on median and & & & & \\
With adjusted df & 0.27 & 1 & 46 & 0.869 \\
Based on trimmed mean & 4.069 & 1 & 46 & 0.050 \\
\hline CG. POTEN & 3.914 & 1 & 46 & 0.054 \\
Based on mean & 3.914 & 1 & 43.83 & 0.054 \\
Based on median & & & & \\
Based on median and & 3.907 & 1 & 46 & 0.054 \\
With adjusted df & & & & \\
Based on trimmed mean &
\end{tabular}

The results of the MANOVA are reported in Table 6. which shows a signficicant effect of the independent variable (teaching through semantic mapping) on both dependent variables by virtue of the $\mathrm{F}$ value of 864.70 , degree of freedom 2 and $p<0.05$.

Table 6. Multivariate Tests (MANOVA)

\begin{tabular}{|c|c|c|c|c|c|c|c|c|}
\hline Effect & Value & $\mathrm{F}$ & $\begin{array}{l}\text { Hypothesis } \\
\text { df }\end{array}$ & $\begin{array}{l}\text { Error } \\
\text { df }\end{array}$ & Sig. & $\begin{array}{l}\text { Partial Eta } \\
\text { Squared }\end{array}$ & $\begin{array}{l}\text { Noncent. } \\
\text { Parameter }\end{array}$ & $\begin{array}{l}\text { Observed } \\
\text { Power }^{\mathrm{a}}\end{array}$ \\
\hline \multicolumn{9}{|l|}{ Intercept: } \\
\hline Pillai’s Trace & .975 & $864.70^{b}$ & 2.00 & 45.00 & .000 & .975 & 1729.402 & 1.000 \\
\hline Wilkis` Lambda & .025 & $864.70^{b}$ & 2.00 & 45.00 & .000 & .975 & 1729.402 & 1.000 \\
\hline Hotelling`s Trace & 38.43 & $864.70^{\mathrm{b}}$ & 2.00 & 45.00 & .000 & .975 & 1729.402 & 1.000 \\
\hline Roy`s Largest & 38.43 & $864.70^{b}$ & 2.00 & 45.00 & .000 & .975 & 1729.402 & 1.000 \\
\hline \multicolumn{9}{|l|}{ Root } \\
\hline \multicolumn{9}{|l|}{ Group } \\
\hline Pillai's Trace & .852 & $129.87^{b}$ & 2.00 & 45.00 & .000 & .852 & 259.742 & 1.000 \\
\hline Wilkis`Lambda & .148 & $129.87^{b}$ & 2.00 & 45.00 & .000 & .852 & 259.742 & 1.000 \\
\hline Hotelling`s Trace & 5.772 & $129.87^{b}$ & 2.00 & 45.00 & .000 & .852 & 259.742 & 1.000 \\
\hline Roy`s Largest & 5.772 & $129.87^{b}$ & 2.00 & 45.00 & .000 & .852 & 259.742 & 1.000 \\
\hline Root & & & & & & & & \\
\hline
\end{tabular}

Table 7 reports on the effect of the independent variable (teaching vocabulary through semantic mapping) on each of the dependent variable of the study (potency and evaluation). 
Table 7. Tests of between-subjects effect

\begin{tabular}{|c|c|c|c|c|c|c|c|c|}
\hline Source & $\begin{array}{l}\text { Type III } \\
\text { Sum of } \\
\text { Squares }\end{array}$ & $\mathrm{df}$ & $\begin{array}{l}\text { Mean } \\
\text { Square }\end{array}$ & $\mathrm{F}$ & Sig. & $\begin{array}{l}\text { Partial } \\
\text { Eta } \\
\text { Squared }\end{array}$ & $\begin{array}{l}\text { Noncent. } \\
\text { Parameter }\end{array}$ & $\begin{array}{l}\text { Observed } \\
\text { Power }^{\mathrm{a}}\end{array}$ \\
\hline $\begin{array}{l}\text { Corrected mod } \\
\text { CG.POTEN } \\
\text { CG.EVALU }\end{array}$ & $\begin{array}{l}1923.93^{\mathrm{b}} \\
1779.93^{\mathrm{b}}\end{array}$ & $\begin{array}{l}1 \\
1\end{array}$ & $\begin{array}{l}1923.926 \\
1779.93\end{array}$ & $\begin{array}{l}47.26 \\
193.08\end{array}$ & $\begin{array}{l}.000 \\
.000\end{array}$ & $\begin{array}{l}.507 \\
.808\end{array}$ & $\begin{array}{l}47.266 \\
193.083\end{array}$ & $\begin{array}{l}1.000 \\
1.000\end{array}$ \\
\hline $\begin{array}{l}\text { Intercept } \\
\text { CG.POTEN } \\
\text { CG.EVALU }\end{array}$ & $\begin{array}{l}9968.43 \\
12614.43\end{array}$ & $\begin{array}{l}1 \\
1\end{array}$ & $\begin{array}{l}9968.42 \\
12614.43\end{array}$ & $\begin{array}{l}244.90 \\
368.39 \\
\end{array}$ & $\begin{array}{l}.000 \\
.000\end{array}$ & $\begin{array}{l}.842 \\
.967\end{array}$ & $\begin{array}{l}244.900 \\
1368.390\end{array}$ & $\begin{array}{l}1.000 \\
1.000\end{array}$ \\
\hline $\begin{array}{l}\text { Group } \\
\text { CG.POTEN } \\
\text { CG.EVALU }\end{array}$ & $\begin{array}{l}1923.93 \\
1779.93 \\
\end{array}$ & $\begin{array}{l}1 \\
1 \\
\end{array}$ & $\begin{array}{l}1923.93 \\
1779.93 \\
\end{array}$ & $\begin{array}{l}47.26 \\
193.08 \\
\end{array}$ & $\begin{array}{l}.000 \\
.000 \\
\end{array}$ & $\begin{array}{l}.507 \\
.808 \\
\end{array}$ & $\begin{array}{l}47.266 \\
193.083 \\
\end{array}$ & $\begin{array}{l}1.000 \\
1.000 \\
\end{array}$ \\
\hline $\begin{array}{l}\text { Error } \\
\text { CG.POTEN } \\
\text { CG.EVALU }\end{array}$ & $\begin{array}{l}1872.37 \\
424.05\end{array}$ & $\begin{array}{l}46 \\
46\end{array}$ & $\begin{array}{l}40.70 \\
9.218\end{array}$ & & & & & \\
\hline $\begin{array}{l}\text { Total } \\
\text { CG.POTEN } \\
\text { CG.EVALU }\end{array}$ & $\begin{array}{l}14151.00 \\
15239.00\end{array}$ & $\begin{array}{l}48 \\
48\end{array}$ & & & & & & \\
\hline $\begin{array}{l}\text { Corrected Total } \\
\text { CG.POTEN } \\
\text { CG.EVALU }\end{array}$ & $\begin{array}{l}3796.31 \\
2203.98\end{array}$ & $\begin{array}{l}47 \\
47\end{array}$ & & & & & & \\
\hline
\end{tabular}

a.computed using alpha $=.05$

b. R squared $=.507$ (adjusted R squared $=.496$

c. $\mathrm{R}$ squard $=.808$ (adjusted $\mathrm{R}$ squared $=.803$

As shown in Table 7 above, the independent variable of "group" had a significant effect on the dependent variable of "potency": $\mathrm{F}_{(1,46)}=47.266 p<0.05$. it is also significant for the dependent variable of evaluation: $\mathrm{F}_{(1,46)}$ $=193.083, \mathrm{p}<0.05$.

The following table shows the pair-wise comparison between the control and experimental groups awareness of the potency and evaluative dimensions of deep vocabulary knowledge.

Table 8. Pair-wise comparisons of control and experimental groups

\begin{tabular}{|c|c|c|c|c|c|c|}
\hline \multirow[t]{2}{*}{$\begin{array}{l}\text { Dependent } \\
\text { Variable }\end{array}$} & \multirow[t]{2}{*}{ (I)group (J)group } & \multirow[t]{2}{*}{$\begin{array}{l}\text { Mean } \\
\text { Difference } \\
\text { (I-J) }\end{array}$} & \multirow[t]{2}{*}{$\begin{array}{l}\text { Std. } \\
\text { error }\end{array}$} & \multirow[t]{2}{*}{ sig $^{\mathrm{a}}$} & \multicolumn{2}{|c|}{$\begin{array}{l}95 \% \text { confidence } \\
\text { Interval for } \\
\text { difference }\end{array}$} \\
\hline & & & & & $\begin{array}{l}\text { Lower } \\
\text { bound }\end{array}$ & $\begin{array}{l}\text { Upper } \\
\text { bound }\end{array}$ \\
\hline \multirow{2}{*}{$\begin{array}{l}\text { CG. } \\
\text { POTEN }\end{array}$} & Controlgroup Experimentalgroup & $-12.673^{*}$ & 1.84 & .000 & -16.38 & -8.96 \\
\hline & Experimental group Controlgroup & $12.673^{*}$ & 1.84 & .000 & 8.96 & 16.38 \\
\hline \multirow{2}{*}{$\begin{array}{l}\text { CG. } \\
\text { EVALU }\end{array}$} & Control group Experimentalgroup & $-12.190^{*}$ & .87 & .000 & -13.95 & -10.42 \\
\hline & Experimental group Control group & $12.190^{*}$ & .87 & .000 & 10.42 & 13.95 \\
\hline
\end{tabular}

Based on estimated marginal means

*.The mean difference is significant at the .05 level

a. Adustment for multiple comparisons: Bonferroni

As illustrated in table 8 , there is a significant difference between the control and the experimentl groups on the potency dimension of the dependent variable $(p<0.05)$ as well as on the evaluative dimension $(p<0.05)$.

The following profile plots show that the experimental group outperformed the control group on potency and evaluation dimension. 


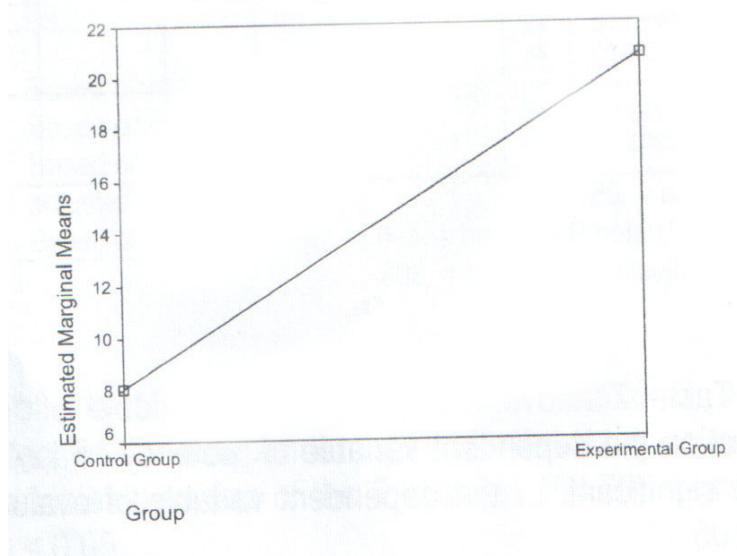

Figure 1. Estimated marginal means of potency

\section{Discussion}

The outcome of the posttest data analysis revealed that the subjects in the experimental group significantly outperformed the subjects in the control group. Therefore, the obvious conclusion is that the devised treatment, i.e. the application of teaching vocabularies through semantic mapping has helped the participants to perform better than those beign taught in the no-semantic-mapping manner in the vocabulary achievement test. Hence, we can conclude that if students are exposed to vocabularies through semantic mapping, they can have better general vocabulary knowledge and improved deep vocabulary awareness in terms of the evaluation and potency dimensions of the skill.

The findings of this study may be benefit to EFL teachers and EFL teaching in general. Teachers can make use of teaching vocabularies in semantic mapping way as a teaching device in their classes. Using semantic mapping may be beneficial in teaching vocabularies because they can create new context for students and learning would be more interesting. When students receive vocabulary instruction in semantic mapping, they can increase deeper knowledge of vocabulary which would help them to use the vocabularies in appropriate situations.

Teachers can utilize a proper type of input to improve the learners' deep vocabulary knowledge. Exposing the students to semantic mapping wll enhance learners' appropriate use of vocabularies. It can be pointed out that in this way, learning vocabularies can be more interesting and more authentic to learners. Semantic mapping can create a more prepatory pretex to achieve deeper knowledge of vocabularies. They can increase the amount of understanding and reducing the amount of difficulties in understanding abstract vocabularies.

\section{References}

American Psychological Association. (1972). Ethical standards of psychologists. Washington, DC: American Psychological Association.

Anderson, C. A., Gentile, D. A., \& Buckley, K. E. (2007). Violent video game effects on children \& adolescents: Theory, research and public policy. http://dx.doi.org/10.1093/acprof:oso/9780195309836.001.0001

Beck, C. A. J., \& Sales, B. D. (2001). Family mediation: Facts, myths, and future prospects. Washington, DC: American Psychological Association. http://dx.doi.org/10.1037/10401-000

Bernstein, T. M. (1965). The careful writer: A modern guide to English usage (2nd ed.). New York, NY: Atheneum.

Bjork, R. A. (1989). Retrieval inhibition as an adaptive mechanism in human memory. In H. L. Roediger III, \& F. I. M. Craik (Eds.), Varieties of memory \& consciousness (pp. 309-330). Hillsdale, NJ: Erlbaum.

Cress, C. M. (2009). Curricular strategies for student success and engaged learning [PowerPoint slides]. Retrieved from http://www.vtcampuscompact.org/2009/TCL_post/presenter_powerpoints/Christine\%20Cress\%20-\%20Curr icular\%20Strategies.ppt

Driedger, S. D. (1998, April 20). After divorce. Maclean's, 111(16), 38-43.

Gibbs, J. T., \& Huang, L. N. (Eds.). (1991). Children of color: Psychological interventions with minority youth. 
San Francisco, CA: Jossey-Bass.

Gilbert, D. G., McClernon, J. F., Rabinovich, N. E., Sugai, C., Plath, L. C., Asgaard, G., ... Botros, N. (2004). Effects of quitting smoking on EEG activation and attention last for more than 31 days and are more severe with stress, dependence, DRD2 A 1 allele, and depressive traits. Nicotine and Tobacco Research, 6, 249-267. http://dx.doi.org/10.1 080/1462220041 0001676305

Goleman, D. (2009). What makes a leader? In D. Demers (Ed.), AHSC 230: Interpersonal communication and relationships (pp. 47-56). Montreal, Canada: Concordia University Bookstore. (Reprinted from Harvard Business Review, 76(6), 93-102, 1998).

Guignon, C. B. (1998). Existentialism. In E. Craig (Ed.), Routledge encyclopedia of philosophy (Vol. 3, pp. 493-502). London, England: Routledge.

Klimoski, R., \& Palmer, S. (1993). The ADA and the hiring process in organizations. Consulting Psychology Journal: Practice and Research, 45(2), 10-36. http://dx.doi.org/10.1037/1061-4087.45.2.10

Kubrick, S. (Director). (1980). The Shining [Motion picture]. United States: Warner Brothers.

MacIntyre, L. (Reporter). (2002, January 23). Scandal of the Century [Television series episode]. In H. Cashore (Producer), The fifth estate. Toronto, Canada: Canadian Broadcasting Corporation.

McLuhan, M. (1970a). Culture is our business. New York, NY: McGraw-Hill.

McLuhan, M. (1970b). From cliche to archetype. New York, NY: Viking Press.

Mellers, B. A. (2000). Choice and the relative pleasure of consequences. Psychological Bulletin, 126, 910-924. http://dx.doi.org/10.1037/0033-2909.126.6.910

Postman, N. (1979). Teaching as a conserving activity. New York, NY: Delacorte Press.

Postman, N. (1985). Amusing ourselves to death: Public discourse in the age of show business. New York, NY: Viking.

Semenak, S. (1995, December 28). Feeling right at home: Government residence eschews traditional rules. Montreal Gazette, p. A4. 